\title{
Effect of variety and plant spacing on yield components of two sorghum varieties
} (Sorghum bicolor 1. Moench)

* ${ }^{1}$ Zakka, T., ${ }^{1}$ Hassan, M. R., ${ }^{2}$ Tanko, R. J, ${ }^{3}$ Munza, B. M. and ${ }^{4}$ Sadiq, A. A.

${ }^{\prime}$ Department of Animal Science, Ahmadu Bello University, Zaria, Nigeria

${ }^{2}$ National Animal Production Research Institute, Shika, Zaria, Nigeria

${ }^{3}$ Department of Animal Science, University of Maiduguri, Maiduguri, Nigeria

${ }^{4}$ Department of Agricultural Education,

Federal Capital Territory College of Education, Zuba, Abuja, Nigeria

Corresponding author: zakkatimothy@gmail.com; +2347061512846

Abstract

The study was conducted to evaluate the effects of variety, plant spacing and stage of harvest on the forage yield components of two sorghum varieties (Sorghum bicolor L. Moench) at the National Animal Production Research Institute Shika, Zaria. The agronomic study was laid in a $2 \times 3 \times 5$ factorial arrangement of a Split Plot Design with three replicates, which consist of two varieties (bush head and sweet sorghums), three plant spacing $(15 \times 85,20 \times$ 85 and $25 \times 85 \mathrm{~cm})$ and five stages of harvest (6, 8, 10, 12 and 14 weeks after sowing), respectively. The forage yield was determined at 14 weeks after sowing (WAS). Leaf length $(68.68 \mathrm{~cm})$, stem diameter $(7.13 \mathrm{~cm})$, number of leaves per plant (12.02) and leaf area index (2.78) were significantly $(p<0.05)$ higher in bush head sorghum variety. Similarly, plant spacing significantly $(p<0.05)$ affected the leaf area index (LAI) with the highest leaf area index recorded in $15 \times 85 \mathrm{~cm}$ plant spacing. There was significant $(p<0.05)$ interaction between variety and plant spacing. Stage of harvest significantly $(p<0.05)$ affected all the growth parameters with 14 weeks having the highest $(223.88 \mathrm{~cm})$ plant height and 10.37 number of leaves per plant and the stage of harvest at 12 weeks after sowing (WAS) recorded the highest $69.84 \mathrm{~cm}$ leaflength, $6.82 \mathrm{~cm}$ leaf width and 2.46 leaf area index. While stage of harvest at 6 and 10 weeks after sowing (WAS) also having the highest number of tillers per plant and stem diameter of 1.24 and $6.47 \mathrm{~cm}$ respectively. Fresh forage yield was significantly $(p<0.05)$ higher $(42.92 \mathrm{t} / \mathrm{ha})$ in bush head sorghum variety not and plant spacing significantly $(p<0.05)$ affected fresh forage and dry matter yields at 14 weeks after sowing (WAS). The highest fresh forage yield (41.81 t/ha) and dry matter yield (7.99 t/ha) were recorded in $15 \times 85 \mathrm{~cm}$ plant spacing. It was concluded, that harvesting of Sorghum bicolor bush head and sweet sorghum varieties for forage is to be best carried out at 14 weeks after sowing for better forage productivity.

Keywords: Variety, Plant spacing, Stage of harvest, bush head sorghum, Sweet sorghum

\section{L'Effet de la variété et de faire de l'espace des plantes sur les composants de rendement de deux variétés de sorgho (sorgho bicolore l. Moench)}

\section{Résumé}

L'étude a été menée pour évaluer les effets de la variété de sorgho, et faisant l'espace des plantes sur les composantes de rendement fourrage de deux variétés de sorgho (Sorgho bicolore L. Moench) à l'Institut National de Recherche sur la Production Animale Shika, Zaria. L'étude agronomique a été posée dans un $2 \times 3 \times 5$ arrangement factorial d'une conception de parcelle divisée avec trois répliques, qui se composent de deux variétés (le 
'bush head' et sorghos sucrés), de trois espacements végétaux $(15 \times 85,20 \times 85$ et $25 \times 85$ $\mathrm{cm})$ et de cinq étapes de récolte $(6,8,10,12$ et 14 semaines après le semailles), respectivement. Le rendement du fourrage a été déterminé à 14 semaines après la semailles $\left(l e e^{\prime} W A S^{\prime}\right)$. La longueur des feuilles $(68,68 \mathrm{~cm})$, le diamètre de la tige $(7,13 \mathrm{~cm})$, le nombre de feuilles par plante (12,02) et l'indice de la superficie des feuilles (2,78) étaient significativement $(p<0,05)$ plus élevés dans la variété de sorgho 'bush head'. De même, l'espacement des plantes de façon significative $(p<0,05)$ a affecté l'indice de la superficie des feuilles (le 'LAI') avec l'indice de superficie folio-feuille le plus élevé enregistré en $15 \times$ espacement des plantes de $85 \mathrm{~cm}$. Il y avait une interaction significative $(p<0,05)$ entre la variété et l'espacement des plantes. L'étape de la récolte a eu une incidence importante $(p<0,05)$ sur tous les paramètres de croissance, 14 semaines ayant la hauteur végétale la plus élevée $(223,88 \mathrm{~cm})$ et 10,37 le nombre de feuilles par plante et le stade de la récolte à 12 semaines après le semis (WAS) ayant enregistré la longueur de feuilles la plus élevée de $69,84 \mathrm{~cm}$, la largeur des feuilles de 6,82 cm et l'indice de la superficie des feuilles de 2,46 feuilles. Alors que le stade de la récolte à 6 et 10 semaines après le semailles (le 'WAS') a également le plus grand nombre de laboureurs par plante et le diamètre de la tige de 1,24 et $6,47 \mathrm{~cm}$ respectivement. Le rendement des fourrages frais était significativement $(p<0,05)$ plus élevé (42,92 t/ha) dans la variété de sorgho de la tête de brousse et l'espacement des plantes de façon significative $(p<0,05)$ affectait les rendements de fourrage frais et de matière sèche à 14 semaines après le semis (le 'WAS'). Le rendement le plus élevé en fourrage frais $(41,81 \mathrm{t} / \mathrm{ha})$ et en matière sèche $(7,99 \mathrm{t} / \mathrm{ha})$ a été enregistré dans $15 \times$ espacement des plantes de $85 \mathrm{~cm}$. Il a été conclu que la récolte de 'bush head' bicolore de Sorgho et des variétés de sorgho sucré pour le fourrage doit être effectuée au mieux 14 semaines après la semailles pour une meilleure productivitéfourragère.

Mots-clés: Variété, Espacement des plantes, Étape de la récolte, sorgho 'bush head', Sorgho sucré

\section{Introduction}

Sorghum is indigenous to Africa, and many of today's varieties originated on that continent. Sorghum is also grown in India before recorded history and in Assyria as early as 700 BC Munza, et al. (2018). The crop reached China during the thirteenth century and the Western Hemisphere much later. Sweet sorghum is an annual crop that can be readily established from seeds and incorporated into existing rotations. It can ratoon following harvest under favourable climatic conditions. It juicy nature has made sweet sorghum a choice bioethanol crop of the semi-arid tropics in the sub-Saharan Africa and India (Reddy et al., 2007). It is a crop of high universal value since it can be cultivated in tropical, subtropical, temperate, and semi-arid regions, as well as in poor quality soils of the world (Rao et al., 2013). It is termed "the sugarcane of the desert" or "the camel among crops" due to its drought hardy characteristics (Sanderson et al., 1992).

Although primarily a grain crop, cultivars and hybrids of sorghum are available that has been why it is selected specifically for high forage biomass (Redfearn et al., 2000 and Blumenthal et al., 2007). The goal in planting, when working with fertile soil, is 50,000 to 300,000 plants per hectare. Yields, have been found to be boosted by $10-15 \%$ when optimum use of moisture and sunlight are available, by planting in $25 \mathrm{~cm}$ rows instead of the conventional 1-meter rows. Sorghum, in general, is a very competitive crop, and does well in competition with weeds in narrow rows. Sorghum produces a chemical compound called sorgoleone, which the plant uses to combat weeds (Ramesh and Aruna, 2016). The chemical is so effective in preventing 
the growth of weeds it sometime prohibits the growth of other crops harvested on the same field. Sorghum is an important summer season crop sown for both fodder and grain purposes. Average fodder yield at present local conditions (Northern Guinea Savannah) is less than the potential of $50-$ 100 tons per hectare. Sorghum can resist drought and hot weather and it can be successfully grown on all types of soils except water logged and saline soils (Chaudhry et al., 2006). However, attributes relating to crop residue improvement has been ignored with emphasis being placed on grain yield (Mohanraj et al., 2011). In view of the pressing demand for fodder coupled with the fact that grain sorghum is a stable diet for millions of poor people, it is imperative to consider other sorghum varieties for forage. Therefore, the study was carried out to evaluate the effect of variety, plant spacing and stage of harvest on the yield components of bush head and sweet sorghum.

\section{Materials and methods}

\section{Description of the experimental site}

The study was conducted during the 2018 rainy season (May - October) at the Experimental Farm of the Feed and Nutrition Research Programme, National Animal Production Research Institute (NAPRI), Shika. The farm is located on
Latitude $11^{\circ} 12^{\prime} \mathrm{W}$, Longitude $07^{\circ} 33^{\prime} \mathrm{E}$ and altitude $660 \mathrm{~m}$ above sea level, $22 \mathrm{~km}$ NorthWest of Zaria in the Northern Guinea Savannah zone of Nigeria (Ovimap, 2015). The climate is characterised by a defined wet and dry season. Wet season in Zaria starts from April to early May and ends in late September to early October. Long-term annual rainfall ranges from 1110 to $1580 \mathrm{~mm}$ with a maximum temperature of $30{ }^{\circ} \mathrm{C}$ and relative humidity of approximately 70\% (IAR, 2018). Weather observations at Shika and environs during the experimental period in 2018 are presented; in Table 1.

\section{Soil characteristics of the study area}

The physiochemical characteristics of the composite soil samples taken from $0-15$ $\mathrm{cm}$ and $15-30 \mathrm{~cm}$ depths of the study area are shown in Table 2. The soil consists of $24 \%-28 \%$ clay $(0-30 \mathrm{~cm}), 24 \%-26 \%$ silt $(0-30 \mathrm{~cm}), 46 \%-52 \%$ sand $(0-30 \mathrm{~cm})$ giving rise to loam and sandy loam, the organic carbon was $0.58 \%$ and $0.48 \%$ for 0 $-15 \mathrm{~cm}$ and $15-30 \mathrm{~cm}$ respectively. The $\mathrm{pH}$ and $\mathrm{CaCl}_{2}$ values obtained shows that the soil is slightly acidic in nature. The soil of the study area is low in both total nitrogen and available phosphorus. The exchangeable cations present are $\mathrm{Ca}^{2+}$, $\mathrm{Mg}^{2+}, \mathrm{K}^{+}$and $\mathrm{Na}^{+}$with an exchange capacity of $6.40 \mathrm{cmol} / \mathrm{kg}(0-15 \mathrm{~cm}), 12.60 \mathrm{cmol} / \mathrm{kg}$ $(15-30 \mathrm{~cm})$ and exchangeable acidity of $0.40 \mathrm{cmol} / \mathrm{kg}(0-15 \mathrm{~cm})$ and $0.60 \mathrm{cmol} / \mathrm{kg}$ $(15-30 \mathrm{~cm})$.

Table 1: Weather observation at IAR during the experimental period

\begin{tabular}{llllll}
\cline { 1 - 3 } Months & $\begin{array}{l}\text { Max. Air Temp } \\
\left({ }^{\circ} \mathrm{C}\right)\end{array}$ & $\begin{array}{l}\text { Min. Air Temp } \\
\left({ }^{\circ} \mathrm{C}\right)\end{array}$ & Rainfall $(\mathrm{mm})$ & $\begin{array}{l}\text { Relative Humidity } \\
(\%)\end{array}$ & $\begin{array}{l}\text { Sunshine } \\
(\text { Hours })\end{array}$ \\
\hline May & 35.58 & 22.03 & $120.6(9)$ & 52.76 & 6.96 \\
June & 33.43 & 20.87 & $144.7(15)$ & 66.20 & 6.21 \\
July & 30.87 & 20.03 & $232.1(12)$ & 78.03 & 6.16 \\
August & 31.16 & 21.48 & $638.1(14)$ & 76.18 & 4.66 \\
September & 31.93 & 18.97 & $256.7(16)$ & 71.40 & 6.43 \\
October & 34.06 & 18.70 & $3(1)$ & 57.29 & 6.63 \\
Total & & & $1395.2(67)$ & & 37.05 \\
Mean & 32.84 & 20.35 & $232.53(11.17)$ & 66.98 & 6.18 \\
\hline
\end{tabular}

Number of rainy days is in parenthesis

Source: IAR 2018 
Table 2: Physical and chemical properties of soil samples collected at the study area

\begin{tabular}{lll}
\hline Soil Properties & $0-15 \mathrm{~cm}$ & $15-30 \mathrm{~cm}$ \\
\hline Particle size (\%) & 28.00 & 24.00 \\
Clay & 26.00 & 24.00 \\
Silt & 46.00 & 52.00 \\
Sand & Loam & Sandy C Loam \\
Textural Class & & \\
Chemical Properties & 0.18 & 0.18 \\
Total Nitrogen (\%) & 0.58 & 0.48 \\
Organic Carbon (\%) & 4.53 & 5.28 \\
Available Phosphorus (ppm) & 6.36 & 6.27 \\
$\mathrm{pH} \mathrm{H}_{2} \mathrm{O}$ & 5.30 & 5.36 \\
$\mathrm{pH}(0.01 \mathrm{M} \mathrm{CaCl} 2)$ & & \\
Exchangeable Cation (meq/100g of soil) & 3.90 & 7.90 \\
$\mathrm{Ca}^{2+}$ & 0.67 & 2.99 \\
$\mathrm{Mg}^{2+}$ & 0.33 & 0.18 \\
$\mathrm{~K}^{+}$ & 0.70 & 0.65 \\
$\mathrm{Na}^{+}$ & 0.40 & 0.60 \\
Exchangeable Acidity (H - $\mathrm{Al}^{3+}$ & 6.40 & 12.60 \\
$\mathrm{Cation} \mathrm{Exchange} \mathrm{Capacity}(\mathrm{CEC})$ &
\end{tabular}

\section{Experimental layout, treatments and design}

A total land area of $30 \mathrm{~m} \times 14 \mathrm{~m}(0.042 \mathrm{ha})$ was used, for the experiment. The field was prepared by ploughing, harrowing and ridging to provide a clean seed bed to enhance early plant germination. The experimental field was divided into 3 main blocks each $(24 \mathrm{~m} \times 4 \mathrm{~m})$ at $1 \mathrm{~m}$ apart and each block was sub-divided into six (6) subplots $(4 \mathrm{~m} \mathrm{x} 4 \mathrm{~m})$ at $1 \mathrm{~m}$ apart.

The varieties as sub-plots were:

- $\mathrm{V}_{1}=$ Bush head sorghum

- $\mathrm{V}_{2}=$ Sweet sorghum

The plant spacing as sub-subplots were:

- $\mathrm{S}_{1}=15 \mathrm{~cm} \times 85 \mathrm{~cm}$

- $\mathrm{S}_{2}=20 \mathrm{~cm} \times 85 \mathrm{~cm}$

- $\mathrm{S}_{3}=25 \mathrm{~cm} \times 85 \mathrm{~cm}$

The spacing systems as subplots were:

For the two sorghum varieties and spacing

$\mathrm{T}_{1}=\mathrm{V}_{1} \mathrm{~S}_{1}$

$\mathrm{T}_{2}=\mathrm{V}_{1} \mathrm{~S}_{2}$

$\mathrm{T}_{3}=\mathrm{V}_{1} \mathrm{~S}_{3}$

$\mathrm{T}_{4}=\mathrm{V}_{2} \mathrm{~S}_{1}$

$$
\begin{aligned}
& \mathrm{T}_{5}=\mathrm{V}_{2} \mathrm{~S}_{2} \\
& \mathrm{~T}_{6}=\mathrm{V}_{2} \mathrm{~S}_{3}
\end{aligned}
$$

The treatments (variety and plant spacing) was replicated 3 times each making a factorial arrangement of $2 \times 3 \times 3$ (2 sorghum varieties, 3 plant spacing and 3 replicates) totaling 18 sub-plots in a Split Plot Design. The seeds of bush head and sweat sorghum varieties were planted on ridges at $2 \mathrm{~cm}$ depth using the treatments combination of the spacing. A uniform seed rate of $15 \mathrm{~kg} / \mathrm{ha}$ was used as recommended by Munza et al. (2017). Weeding was done manually using hoe at three (3) and six (6) weeks after planting, so as to control weed. A uniform dose of $120 \mathrm{kgN} / \mathrm{ha}$, was applied to the plants at 3 weeks after sowing and $75 \mathrm{~kg} /$ ha Urea was applied at 6 weeks as second dose of fertilizer as recommended by (Ashwini et al., 2017).

\section{Source of experimental materials}

Bush head and sweet sorghum varieties were sourced from National Animal Production Research Institute (NAPRI) Shika. The seeds of the sorghum varieties were planted in the month of June when rain was fully established. 


\section{Data collection \\ Growth parameters}

After crop establishment, a seed establishment count was conducted along $200 \mathrm{~cm}$ length of 3 middle ridges of each plot and the result was expressed in plants $/ \mathrm{m}^{2}$. Field emergence was calculated by dividing seedling emergence by seeds planted $/ \mathrm{m}^{2}$. Seedling was considered emerged when coleoptile was visible above soil (Brar and Stewart, 1994 as cited by Davision, 2011). Data on crop phenology of the treatment combinations were measured at $6,8,10,12$ and 14 weeks after sowing. Five (5) plants were randomly selected and tagged (per plot) for the measurements of various agronomic parameters using the standard procedure as reported by Tarawali et al. (1995). Forage sampling was done at 9 and 14 weeks after sowing for chemical analysis.

\section{Stand counts}

The number of emerged plant stands per plot was counted at 15 days after sowing in each plot.

\section{Plant height}

The plant height of bush head and sweet sorghum varieties were determined by measuring from the base of the plant to where the last leaf on the stem emerges with the aid of a tape rule on 5 randomly tagged plants per plot at $6,8,10,12$ and 14 weeks after sowing.

\section{Number of leaves per plant}

The number of leaves on the five randomly selected and tagged plants of both bush head and sweet sorghum were counted and the mean number of the leaves per plant was determined from each plot at 6, 8, 10, 12 and 14 weeks after sowing.

\section{Leaflength}

Leaf length of bush head and sweet sorghum varieties were estimated by measuring from the tip of the leaf to the base of the ligules for all the leaves on the plants with the aid of tape rule from the 5 randomly tagged plants per plot at $6,8,10,12$ and 14 weeks after sowing.

\section{Leaf width}

Leaf width were determined by measuring the width of leaf half way or midpoint of the leaf length with the aid of $30 \mathrm{~cm}$ meter rule on the 5 randomly tagged plants per plot for all the leaves on the plants at 6, 8, 10,12 and 14 weeks after sowing.

\section{Tiller number}

Tiller number was determined by counting the number of tillers of 5 of the randomly tagged plants per plot at $6,8,10,12$ and 14 weeks after sowing.

\section{Leaf area index}

Leaf area index was determined using the method described by Watson (1952). i.e LAI is the ratio of leaf area multiply by a factor $(0.75)$ to the unit ground area covered by each plant.

LAI $=\underline{\text { Leaf number } x \text { leaf length }(\mathrm{cm}) \quad \mathrm{x}}$ leaf width $(\mathrm{cm}) \times 0.75$

$$
\text { Leaf area }(\mathrm{cm})
$$

\section{Determination of fresh forage and dry matter yield}

This was determined at 14 weeks which marks the end of the agronomic trial by harvesting the fresh forage at $5 \mathrm{~cm}$ from the ground using machetes within each sub-plot in a $1 \mathrm{~m}^{2}$ quadrat. Total fresh forage was weighed and a sub sample of $(150-200 \mathrm{~g})$ was taken and oven dried at $65^{\circ} \mathrm{C}$ for 48 hours and reweighed to estimate dry matter yield.

Dry matter production was calculated as: $(\mathrm{FW} \times(\mathrm{DWss} / \mathrm{FWss})) \times 10=$ Dry matter $\mathrm{kg} / \mathrm{ha}$. (Tarawali et al., 1995) where:

$\mathrm{FW}=$ Fresh weight from $1 \mathrm{~m}^{2}$ in $(\mathrm{g})$

DWss $=$ Dry weight of the sub-sample in $(\mathrm{g})$ FWss $=$ Fresh weight of the sub-sample in (g).

\section{Statistical analysis and models}

Data collected from the field trial was analysed using the repeated measure ANOVA of SAS (2005). Means that were significantly different were compared using least significant differences (LSD) at 5\% 
$(p \leq 0.05)$ probability level of the SAS package.

\section{Experimental model}

$\mathrm{Y}_{\mathrm{i} \mathrm{i},}=\mu+\mathrm{A}_{\mathrm{i}}+\mathrm{B}_{\mathrm{i}}+\left(\mathrm{A}^{*} \mathrm{~B}\right)_{\mathrm{i} \mathrm{k}}+\mathrm{E}_{\mathrm{i} \mathrm{k} \mathrm{k}}$

Where:

$\mathrm{Y}_{\mathrm{ij \textrm {k }}}=$ is the record of observation

$\mu=$ is the population mean

$A_{i}=$ effect of spacing $(j=15 \mathrm{~cm}, 20 \mathrm{~cm}$ and $25 \mathrm{~cm})$

$\mathrm{B}_{\mathrm{j}}=$ effect of variety $\left(\mathrm{V}_{1}=\right.$ Bush head sorghum, $V_{2}=$ Sweet sorghum)

$\mathrm{A}_{\mathrm{i}} \times \mathrm{B}_{\mathrm{j}}=$ effect of spacing and variety (interaction)

$\mathrm{E}_{\mathrm{ij}}=$ random error

\section{Results and discussion \\ Growth components of sorghum (Sorghum bicolor)}

The significant effect of variety on leaf length, stem diameter, number of leaves per plant and leaf area index was in agreement with the findings of Hamed et al. (2015) who reported significant differences on growth parameters, dry matter yield and grain yield respectively among different sorghum varieties.

The report showed no significant effect of plant spacing on stand count per plot, plant height, leaf length, leaf width, number of tillers per plant, stem diameter and number of leaves per plant, this was not in agreement with the findings of Munza, et al. (2018) who reported significant effect of plant spacing on stand count per plot, leaf width and leaf area index respectively. However, the significant effect of plant spacing on leaf area index was in agreement with the observation of Munza et al. (2018) who reported a significant difference in the leaf area. The findings were not in agreement with the findings of Ishiaku et al. (2016) who reported that plant spacing does not affect the leaf area index of forage sorghum. Leaf area index is an important measure of the size of the assimilatory system of the plant and it is mainly concerned with the accumulation and partitioning of the photosynthetic part of the plant. It plays an important role in the final biomass of the crop. The leaf area index reported in this study $(1.31-2.31)$ were slightly higher than the values $(1.22-2.06)$ reported by Munza et al. (2018) using grain sorghum and slightly lower than the range of $(2.14-2.42)$ as reported by Ishiaku et al. (2016) using Sorghum almum. These variations may be attributed to variety, some environmental factors such as temperature, light, soil fertility, genetic characteristics, pasture management, plant age, and especially water availability, which are essentially linked to the variation of leaf area index among forage species. The significant effect of stage of harvest on all growth parameters measured is in agreement with the reports of Munza et al. (2018) and Ishiaku et al. (2016) who noted an increasing trend in all the growth components as the stage of harvest advanced. There was an increasing trend of $7.45 \%, 14.93 \%, 22.74 \%, 25.94 \%$ and $28.94 \%(\mathrm{P}<0.05)$ in plant height as the stage of harvest advanced from 6 to 14 weeks after sowing (WAS). The leaf length $(17.92 \%-28.88 \%)$ and leaf width $(19.73$ $\%-27.69 \%$ ) increased with advanced increase in stage of harvest from 6 to 12 weeks after sowing (WAS). The stem diameter, number of leaves per plant and leaf area index increased with increasing stage of harvest from 6 to 8 weeks after sowing (WAS). While the number of tillers per plant decreased with advanced increased in stage of harvest from 6 to 12 weeks after sowing (WAS). This may be attributed to stand density and distribution within rows spacing as under low plant populations, tillers may be large and numerous. 
Table 3: Effects of variety, plant spacing, stage of harvest and theimiteraction on growth components of bush head and sweet sorghum varieties

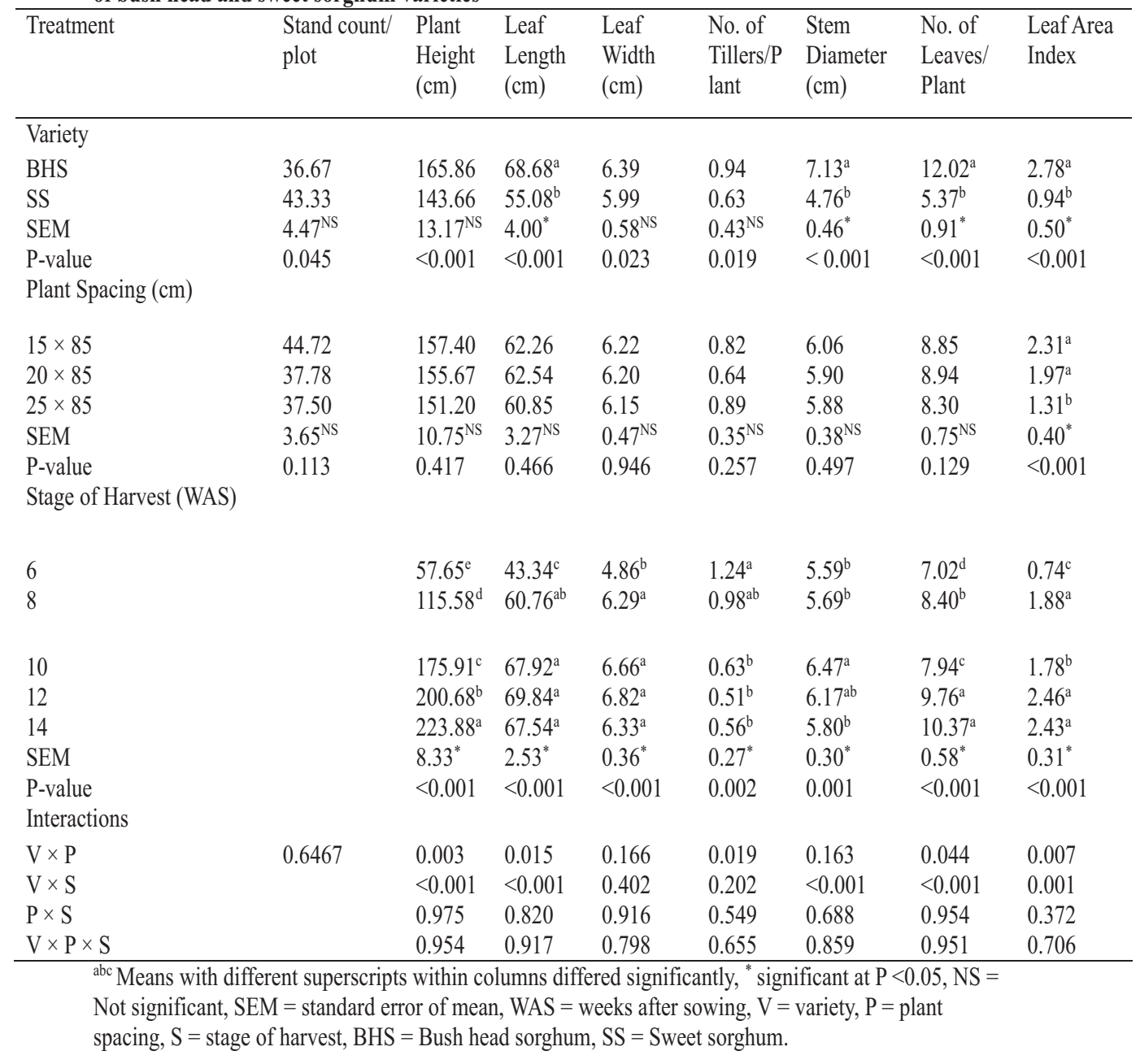

Fresh and dry matter yields of bush head and sweet sorghum forages

This study shows significant effect in the fresh forage yield between the two varieties of sorghum and the dry matter yield of both varieties were not significantly $(\mathrm{P}>0.05)$ different between varieties. The fresh forage yield of bush head sorghum (42.92 $\mathrm{t} / \mathrm{ha}$ ) and sweet sorghum (25.73 t/ha) reported in this study was not in agreement with the findings of Ghasemi et al. (2012), who reported the fresh and dry matter forage yields of different sorghum varieties to be between $153.427 \mathrm{t} / \mathrm{ha}$ to $102.019 \mathrm{t} / \mathrm{ha}$ and 6.94 to $39.21 \mathrm{t} / \mathrm{ha}$ respectively.
However, the dry matter yield of bush head sorghum (4.49 t/ha) and sweet sorghum $(4.88 \mathrm{t} / \mathrm{ha})$ of this findings was within the range $4.4 \mathrm{t} / \mathrm{ha}$ to $19.13 \mathrm{t} / \mathrm{ha}$ which were found significant among sorghum cultivars with respect to fodder yield as reported by Singh et al. (2014). The significant $(\mathrm{P}<0.05)$ effect of plant spacing on fresh and dry matter yield of sorghum recorded in this study was not in agreement with the findings of Munza et al. (2018) who reported that plant spacing does not affect fresh and dry matter yield of grain sorghum. The fresh forage yield obtained were 41.81 t/ha, 34.00 t/ha and $27.18 \mathrm{t} / \mathrm{ha}$ for plant 
spacing $15 \times 85 \mathrm{~cm}, 20 \times 85 \mathrm{~cm}$ and $25 \times 85$ $\mathrm{cm}$ respectively. While the dry yields obtained in the study were $7.99 \mathrm{t} / \mathrm{ha}, 6.82$ $\mathrm{t} /$ ha and $5.25 \mathrm{t} /$ ha for spacing $15 \times 85 \mathrm{~cm}, 20$ $\times 85 \mathrm{~cm}$ and $25 \times 85 \mathrm{~cm}$ respectively. However, the values of both fresh and dry matter yields obtained from this study was similar to the report of Munza, et al. (2018) who reported the fresh forage yields of grain sorghum to be $38.06,33.44$ and 36.44 t/ha for $15 \times 85,20 \times 85$ and $25 \times 85 \mathrm{~cm}$ plant spacing, respectively. And dry matter yields of 9.06, 7.54 and $7.92 \mathrm{t} /$ ha DM for plant spacing $15 \times 85,20 \times 85$ and $25 \times 85 \mathrm{~cm}$, respectively. The study showed that fresh and dry matter yields decreased with increasing plant spacing which was attributed to more plant population per unit area in narrow spacing which ultimately contributed to increased forage yield as compared to wider spacing with less plant population per unit area which was in agreement with the findings of Saeed et al. (1996), who reported that green fodder yield decreased as plant spacing was increased.

Table 4: Effect of variety, plant spacing and their interaction on fresh and dry matter yields of bush head and sweet sorghum varieties at 14 weeks after sowing (WAS)

\begin{tabular}{lcc}
\hline Treatment & Fresh Forage Yield (t/ha) & Dry Matter Yield (t/ha) \\
\hline Variety & & \\
BHS & $42.92^{\mathrm{a}}$ & 4.49 \\
SS & $25.73^{\mathrm{b}}$ & 4.88 \\
SEM & $6.30^{*}$ & $1.31^{\mathrm{NS}}$ \\
P-value & $<0.001$ & $<0.001$ \\
Plant Spacing $(\mathrm{cm})$ & & \\
$15 \times 85$ & $41.81^{\mathrm{a}}$ & $7.99^{\mathrm{a}}$ \\
$20 \times 85$ & $34.00^{\mathrm{ab}}$ & $6.82^{\mathrm{ab}}$ \\
$25 \times 85$ & $27.18^{\mathrm{b}}$ & $5.25^{\mathrm{b}}$ \\
SEM & $5.14^{*}$ & $1.07^{*}$ \\
P-value & 0.002 & 0.005 \\
Interaction & & \\
V $\times$ P & 0.2420 & 0.2408 \\
\hline
\end{tabular}

${ }^{a b c}$ Means in same column with different superscript differs significantly, * significant at $\mathrm{P}<0.05, \mathrm{NS}=$ Not significant, $\mathrm{SEM}=$ Standard error of mean, BHS $=$ Bush head sorghum, $\mathrm{SS}=$ Sweet sorghum, $\mathrm{V}=$ Variety, $\mathrm{P}=$ Plant spacing.

\section{Conclusion and recommendations}

It was therefore concluded that sweet sorghum variety produced the highest number of stand counts and bush head sorghum cultivar produced the highest plant height, leaf length, leaf width, number of tillers per plant, stem diameter, number of leaves per plant and leaf area index. Plant spacing $15 \times 85 \mathrm{~cm}$ produced the highest number of stand counts, plant height, leaf width stem diameter and leaf area index. Stage of harvest at 14 weeks after sowing (WAS) recorded the highest plant height and number of leaves per plant while stage of harvest at 12 weeks after sowing (WAS) produced the highest leaf length, leaf width and leaf area index. Harvesting of Sorghum bicolor bush head and sweet sorghum varieties for forage could best be carried out at 14 weeks after sowing for better forage productivity.

\section{References}

Ashwini, C., Ardeshna, R. B., Subhra, S. and Saladi, M. 2017. Response of summer sorghum (Sorghum bicolor L. Moench.) to Spacing and nitrogen levels. International Journal of Chemical Studies, 6(3): 3256-3258

Blumenthal, J. B., Rooney, W.L. and Wang, D. 2007. Yield and ethanol 
production in sorghum genotypes.Agron, Abstract [CDROM]. ASA, Madison, Wisconsin.

Chaudhry, G. N., Riaz, M. and Ahmad, G. 2006. Comparison of some advanced lines of Sorghum bicolor L Moench for green fodder/dry matter yields and morphoeconomic parameters. Journal of Agricutural Research, 44: 191196.

Davision, S. 2011. Evaluation of forage yield and quality of sorghum, sudan grass and pearl millet cultivars in Manawatu. Msc Thesis presented to Department of Agronomy, Massey University, Palmerston North, Newzealand.

Ghasemi, A., Karim, M. H. and Ghasemi, M. M. 2012. Green Food Yield Performance of Different Varieties of Sorghum in an Arid Region. International Journal of Agriculture and Crop Sciences 2(4): 839-843.

Hamed, A. H., Abbas, S. O., Ali, K. A., and Elimam, M. E. 2015. Stover yield and chemical composition in some sorghum varieties in Gadarif state, Sudan. Animal Review, 2(3), 68-75.

IAR 2018. Institute for Agricultural Research, Ahmadu Bello University, Zaria. Meteorological Data Information of Samaru and its Environs.

Ishiaku, Y. M, Hassan, M. R., Tanko, R. J., Amodu, J. T., Abdu, S.B., Ahmed, S. A., Abubakar, S.A., Lasisi, O.T., Bala A. G., Bello, S. S and Ibrahim, H. 2016. Effect of plant spacings on yield and quality of columbus grass (Sorghum almum) under rainfed condition in Shika, Nigeria. Journal of Animal Production Research, 28(1), 318-
328.

Mohanraj, K., Gopalan, A., Durai, A. A., and Ravinder, K. 2011. Genetic variability for grain cum fodder yield and contributing traits in F2 generations of dual purpose sorghum. Plant Archives, 11(1), 151-156.

Munza, B. M., Hassan, M. R., Tanko, R. J., Amodu, J. T., Abdu, S. B., Ishiaku, Y. M., Salisu, S. G. and Zakka, T. 2017. Effect of seed rate on forage yield and quality of grain sorghum (Sorghum bicolor L. Moench) under rain fed in Shika, Nigeria. Journal of Animal Production and Research, 29(1): 321-330.

Munza, B. M., Hassan, M. R., Tanko, R. J., Akpensuen, T. T. and Usman, A. 2018. Forage yield and quality of grain sorghum (sorghum bicolor (1). Moench) as influenced by plant spacing and stage of harvest in a Northern Guinea Savanna of zone of Nigeria. Nigerian Journal of Animal Science and Technology. 1(2): 71-85.

Ovimap, 2015. Ovi location map: Ovi Earth Imagery Data.

Ramesh, B. and Aruna, M. 2016. Cultivation and utilization of sorghum bicolor (L.) for better health of tribals's in Telangana State, India - A Resume. Life Sciences International Research Journal: 3: 56-61.

Rao, P. S., Kumar, C. G., Reddy, B. V. S. 2013. "Sweet Sorghum: from theory to practice", in: P. Rao, S., Kumar, C. G. (Eds.), Characterization of Improved Sweet Sorghum Cultivars, Springer Briefs in Agriculture, India, pp 1 - 15.

Reddy, B. V. S., Kumar, A. and Ramesh, S. 2007. Sweet sorghum: a water 
saving bioenergy crop. ICRISAT, International Conference on Linkages Between Energy and Water Management for Agriculture in Developing Countries, January 29- 30, IWMI, ICRISAT Campus, Hyderabad, India.

Redfearn, D., Venuto, B., Twidwell, E., Hogan, A., Wicke, G. and Shields, T. 2000. Growing summer annuals as a forage option. Louisiana Cattleman, 33, 8-15.

SAS. 2005. Statistical Analysis Software (CD-ROM), Version 8.1, SAS Institute Inc., Cary, N.C., USA.

Saeed, M., Siddiqui, N.A., Maqsood., M. and Mahmood, T. 1996. Effect of nitrogen and plant spacing on growth, green fodder yield and quality of Mott elephantgrass. Pakistan Journal of Science and Industrial Resources. 39: 54-59.

Sanderson, M. A., Jones, R. M., Ward, J. and Wolfe, R. 1992. "Silage sorghum performance trial at Stephenville", Forage Research inTexas, Report PR-5018, Texas Agricultural Experiment Station,
Stephenville 68.

Singh, P. K., Gautam, R. K., Dam Roy, S., Awnindra, K. S. and Zamir, S. K. 2014. Performance of sorghum varieties for fodder yield during rabi season in Andaman and Nicobar Island. Journal of the Andaman Science Association, 19(2):174-176.

Tarawali, S. A., Tarawali, G., Larbi, A. and Hanson, J. 1995. Methods of evaluation of legumes, grasses and fodder trees for use as livestock feed. Livestock International Research Institute, Manual. Nairobi, Kenya. Pp 1-2.

Watson, D. J. 1952. The dependence of net assimilation rate on leaf index. Annals of Botany, 22:37-54.

Received: $17^{\text {th }}$ October, 2020 Accepted: $6^{\text {th }}$ February, 2021 